
www.globaljournalseries.com, Email: info@globaljournalseries.com

\title{
CLIMATIC INFORMATION AS EVIDENCE OF DESERTIFICATION PROCESSES IN NORTHERN YOBE STATE, NIGERIA: IMPLICATIONS FOR AGRICULTURE AND ECOSYSTEM
}

\author{
AMBROSE A. ZEMBA, YARIMA UMAR AND NANKAP L. BINBOL
}

(Received 19 June 2017; Revision Accepted 21 November 2017)

\begin{abstract}
This study was formulated to investigate the potential contribution of climatic parameters to desertification processes in northern Yobe State, Nigeria. Rainfall and temperature data for 43 years were obtained from the Nigeria Meteorological (NiMet) office Maiduguri and subjected to statistical and agro-climatological analysis. Results indicate that the study area has characteristics of a typical semi-arid environment with annual rainfall and temperature totals of $432.3 \mathrm{~mm}$ and $34^{\circ} \mathrm{C}$ respectively. These parameters are highly variable over the year with considerable biological impact and may well show how the area's ecosystem will experience and respond to future climate change. Trend analysis further confirmed that these variables fluctuate greatly. A shift in rainfall pattern in recent years was observed with high intensity recorded in July as against August previously. There has been a gradual delay in onset and early cessation of rains in the area. Hydrologic ratio of 0.255 further demonstrates an arid condition of the region with a seasonality index of 1.18, meaning that rain falls within just 3 months in the area. The index of replicability and quantity of water needed (Specific Water Consumption) to avert drought shows that the area is getting drier. All of these point to the presence of desertification processes in the region. Desertification mitigation measures such as massive tree planting campaign need to be put in place to avert negative consequences of the phenomenon.
\end{abstract}

KEYWORDS: Agro-climatology, Desertification, Rainfall, Temperature, Yobe.

\section{INTRODUCTION}

It has been widely documented (Veron et al 2006, Mainguet 1994, Williams and Balling 1996, Reynolds and Stafford 2002) that desertification has been and still taking its toll in the environment and by extension, human livelihoods of the arid and semi-arid regions of the world. Though, it has no widely acceptable definition, but the one given by United Nations (UN 1994) as "desertification is land degradation at arid, semi-arid and dry sub-humid areas resulting from various factors including climatic variations and human activities" is commonly recognized and used by most researchers (Hellden 1988). It implies a degradation in land quality of vegetation, soil and water as a result of climatic variability or changes and human activities. A number of authors have reported incidence of desertification in their research findings. In Nigeria, for example, Adetunji 2006, Baka and Jajere (2010 in Sawa and Adebayo 2015), Emodu 2013, Haruna and Bukar 2010, Olaganju and Temidayo 2015 and Nich (2012 in Umar 2015) have all posited that desertification is occurring especially in the semi-arid environment adjoining the Sahara desert in northern Nigeria. Some of these researchers have made use of such statements as "desert is encroaching at the rate of $5.5 \mathrm{~km}$ per annum (Lamprey 1975); desert is expanding at $6 \mathrm{~km}$ per annum and $70 \%$ of all drylands is affected by desertification (UNEP 1992); desertification shows an increase from 48 to 117 hectares of lands from 1984 1991 " and so on to describe the environmental condition in Nigeria. All of the above statements demonstrate how serious the phenomenon is in Nigeria.

However, various researchers (Hellden 1988, 1991; Tucker et al 1991; Nicholson 1998; Prince et al 1998) have questioned the methodology employed by previous researchers above and found no evidence for extensive desertification. Recently, some researchers (e.g. Huenneke et al 2002, Veron et al 2006) have suggested that there were methodological or conceptual problems, which illustrate that desertification assessment remains controversial. This is further confirmed by the United Nations Convention to Combat Desertification's (UNCCD 2000) statement that "to date, although a great deal of data on land resources are available, it has not been possible to get a clear picture of the states of land degradation at a regional or national levels. This opens the door for misuse of concept of desertification.

Interestingly, Veron et al (2006) state that the ongoing debate about the very nature of desertification does not necessarily imply that there should not be consensus on the method to assess desertification status. In general, the debate upon the nature of

Ambrose A. Zemba, Geography Department, Modibbo Adama University of Technology, Yola, Nigeria.

Yarima Umar, Desert Research Monitoring and Control Centre, Yobe, Yobe State, Nigeria.

Nankap L. Binbol, Department of Geography \& Planning, University of Jos, Nigeria. 
desertification is centred on issues such as its causes, consequences, if it is reversible or not, the relative importance of socioeconomic or methodological aspects etc. On the contrary, a methodology to assess desertification impact should quantify its effects independently of other issues.

Desertification, like climate change and loss of biodiversity, is a global problem (Pickup 1996). The severity of its impact varies in the same way as its causes. The less developed countries tend to experience greater human misery than those with the resources to provide short and long term relief to affected populations. This is why desertification problems have become inextricably linked with those of food security, poverty alleviation and lack of development in poor countries while in richer countries the emphasis is on environmental degradation, inappropriate land use, loss of biodiversity and rural restructuring. Desertification problems have also become linked with long term droughts which have affected some parts of the world such as the African Sahel recently and were experienced in large parts of Australia in the 1890s, 1920s and 1960s.

The definition of UNCCD (2000) is unambiguous on the issue of what and where, but the question of why is not clearly answered. This is simply because there are two polarized views on the causes of desertification (Warren and Khojal 1992). At one extreme is the view that traditional land use systems are often well adapted to periodic drought (e.g. Ellis et al 1993). Desertification therefore, tends to be human induced and arises because of pressure on land resources due to rising populations, unwise development policies and misuse of the land (e.g. Graetz 1996). At the other extreme is the view that drought, which is normally a short term natural fluctuation in climate, accelerates the long term rate of land degradation (Hill and Peter 1996). This implies that when long term reductions in rainfall occurs, such as those which affected parts of African Sahel (study area inclusive) over the last 40 years or so, the resultant degradation is a largely natural phenomenon and beyond the control of nations experiencing it. The later view is explored in this study so as to understand how climate variability contributes to desertification processes in the study area.

The study is an attempt to evaluate the climatic variables with a view to assessing their potential contribution to causes of desertification in a part of Nigeria, a developing country with a large semi-arid zone whose principal land use is crop farming and pastoralism. Interestingly, Yobe State of Nigeria is located in the semi-arid region with mean annual rainfall of about 443.92mm (Umar 2015) that falls within 3 to 4 months. Its position within the risk zone of desertification, coupled with its domination by less palatable plants as well as the reported extinction of wildlife species (Le Houerou 2002) all present strong evidence of the seriousness of desertification problem in this area, hence the need for a study like this.

\subsection{The Study Area}

The northern part of Yobe State, Nigeria is the study area for this study. It is situated between latitudes $12^{\circ} 00^{\prime}$ and $13^{\circ} 28^{\prime} \mathrm{N}$ and longitudes $9^{\circ} 45^{\prime}$ and $12^{\circ} 30^{\prime} \mathrm{E}$, bordered by Niger Republic to the north; Jigawa and Bauchi States to the west; Nagere, Fune and Tarmua LGAs in the south and Borno State to the east (Fig 1). 


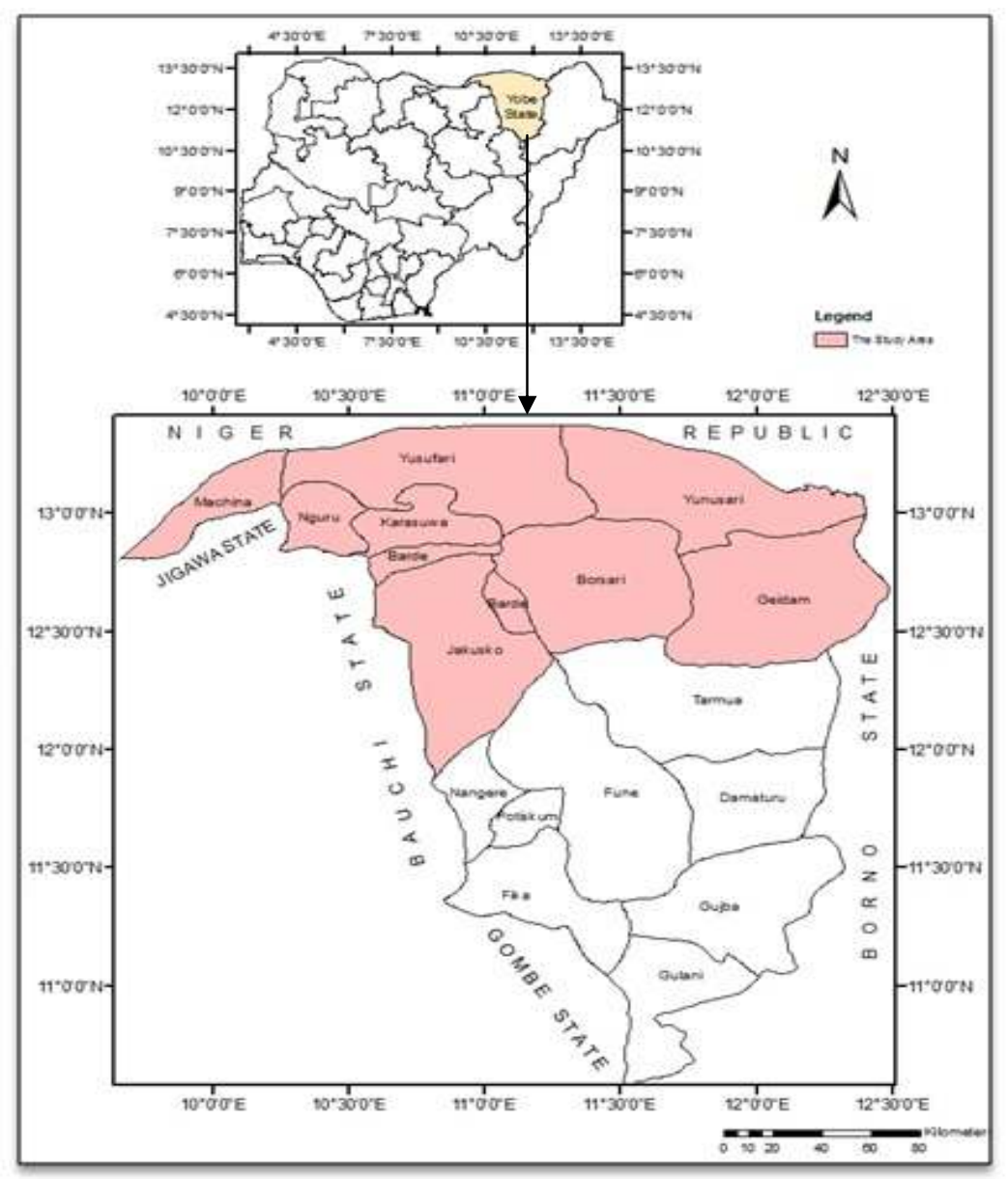

Fig. 1: Yobe State showing the Study Area

Yobe has tropical climate characterized by distinct wet and dry seasons. The dry season is associated with the prevalence of dry continental airmass of the North East Trade Wind (NETW), which originates from Sahara desert. The wet season is associated with the moist maritime southerly airmass which originates from the Atlantic Ocean. The area experiences uniform weather with rainfall attaining its peak in August; though there seems to be a shift of this to July in recent times. The mean annual rainfall of the area is put at $450 \mathrm{~mm}$ with an average onset and cessation dates in June and September respectively (Sawa and Adebayo 2015). One of the distinguishing characteristics of the area is its low rainfall that lasts for only three to four months (Umar 2015). The average daily temperature is about $25^{\circ} \mathrm{C}$ with a monthly mean value of about $27^{\circ} \mathrm{C}$. However, mean maximum temperature for the hotter months goes as high as $40^{\circ} \mathrm{C}$ especially in the months of April, May and June (Baka and Jajere 2011). The average relative humidity for the months of December and January is about $30 \%$ (driest period) and goes as high as to an average of $70 \%$ in wettest months (August and September).

Yobe state generally is described as a major wetland in the semi-arid corridor, supporting over one million people (FAO 2006; NPC 2006). The region falls within the extensive landscape of Borno plain. Dominating the relief, soils and ecology of the area are fixed dunes, low sand hills varying from 10-30meters in heights and $300-400$ meters in width with NE to SW direction, sometimes reaching several kilometers in length (Adams and Hollis 1987). These sand dunes were formed and are active in the arid phase of the southern Sahara some 15,000 years. The main inland drainage in the area is River Yobe and its tributaries which cover a distance of about $400 \mathrm{~km}$. The natural flow regime of the river is highly seasonal with high flows in the rainy season and low to zero flows during dry seasons. Others include Komaduga-Gana system, which passes through Dapchi in the western part. Other seasonal streams are also found in the area. The lower part of River Yobe forms part of the international boundaries between Nigeria and Niger Republic. The thick deltaic deposit, which marks the entrance of rivers into Lake Chad, makes the production of rice possible, while fishing is practiced in almost all the tributaries and streams especially in areas like Gogaram (Baka and Jajere 2011).

The area has tropical vegetation characterized by scattered shrubs, thorns of acacia species, tamarind, baobab and some edulious plants. The trees are xerophytic in nature intersperse with short seasonal grasses. These are supported by pedosals and pedalfers soils rich in irons and calcium respectively. However, the natural vegetation of this region has been seriously tempered with mainly by anthropogenic factors. Floodplains provide important dry season pastures, exploited in particular by nomadic pastoralists while subsistent crop cultivation is practiced on the available plain lands in large scale. 


\subsection{MATERIALS AND METHODS}

This study was aimed at analyzing the climatic data of rainfall and temperature with a view to assessing their potentials in contributing to desertification processes in the study area. Rainfall and temperature data were collected for 43 years (1974-2016) from the Nigeria Meteorological (NiMet) office at International Airport, Maiduguri, Nigeria. Two main analyses were conducted in the study. These include statistical and agro-climatological analyses.

\subsection{Statistical Analysis}

Rainfall and temperature data were subjected to different descriptive statistical analysis principally to derive means, standard deviations, variance and coefficient of variations. The data were also subjected to time series analysis. Year to year variability in rainfall and temperature were smoothed by the 5 -year moving average. Linear trend lines and best fit trend line equations were plotted for the rainfall and temperature graphically using EXCEL software of the computer.

\subsection{Agro-climatological Analyses}

Agro-climatological analyses undertaken had to do with derivation of precipitation effectiveness indices including onset and cessation dates of rains, length of rainy season, seasonality index, hydrologic ratio and Specific Water Consumption (SWC).

Onset date of rain refers to the time a place receives an accumulated amount of rainfall sufficient for growing of crops. It is not however, the first day the rain falls. Cessation date on the other hand, means termination of the effective rainy season. It refers to a situation when rainfall can no longer be assured or be effective. Researchers who have defined onset and cessation include Walter (1967), Kowal and Knabe (1972), and Olaniran (1988). Adefolalu's (1993) method of determining onset (start) and cessation (end) dates of growing season was adopted in this research. The formula used to determine onset and cessation dates is: Days in the month $x \frac{51-\text { accumulated rainfall of previous months }}{\text { Total rainfall the month }}$

Where the month under reference is that in which the accumulated monthly rainfall is in excess of
$51 \mathrm{~mm}$. For the cessation date of rain, the formula was applied in reverse order from December.

Length or rainy season (LRS) refers to the number of days it takes for rain to fall in a given rainy season. It is determined by subtracting the onset pentad from the cessation pentad and multiplying the difference by 5 (i.e. number of days in a pentad). Adefolalu (1993) noted that the ogive method is more accurate than the others. Thus, this was adopted in this study.

Hydrologic ratio is the degree of wetness or dryness of a place. It is defined as the ratio of the mean annual rainfall $(P)$ to the Potential Evapotranspiration (PE) (Adefolalu 1998, Adebayo and Adebayo 1997). The values indicate soil moisture surplus or deficiency. It is one of the best methods of estimating water availability as soil moisture. Thus, it is the most appropriate drought indicator, which not only gives an indication of the adequacy of rainfall but also serves as empirical measure of the contribution of drought tendency in the desertification processes (Sawa and Adebayo 2015). The higher the value of hydrologic ratio, the drier is the wet season and vice-versa. Hydrologic ratio was mathematically derived by the equation: $H R=P / P E$, where,

$\begin{array}{lll}\mathrm{HR} & = & \text { Hydrologic ratio } \\ \mathrm{P} & = & \text { Precipitation } \\ \mathrm{PE} & = & \text { Potential Evapotranspiration. }\end{array}$

Seasonality index is the measure of the spread and steadiness of the rainfall during the wet season. Walsh and Lawler (1981) expressed seasonality index as the sum of the absolute deviations of the mean monthly rainfall from the overall monthly mean multiplied by the exponent of the mean annual rainfall. This is determined by the equation:

$$
\begin{array}{lll}
S I & = & 1 /{ }_{R} \sum|\overline{x n}-R / 12|, \text { where: } \\
\text { SI } & = & \text { Seasonality Index } \\
\mathrm{R} & = & \text { Mean annual rainfall } \\
\overline{x n} & = & \text { Mean rainfall of the month } \mathrm{n}
\end{array}
$$

The values of seasonality index obtained in this research were compared with Walsh and Lawler's (1981) values (Table 1) for interpretation and possible classification of the study area into a given rainfall regime.

Table 1: Classification of Seasonality Index of Rainfall

\begin{tabular}{lll}
\hline S/n & SI Class & Rainfall Regime \\
\hline 1 & $\leq 0.19$ & Very equitable (no month without rain) \\
2 & $0.20-0.39$ & Equitable but with definite wetter season \\
3 & $0.40-0.59$ & Rather seasonal with a short dry season \\
4 & $0.60-0.79$ & Seasonal \\
5 & $0.80-0.99$ & Markedly seasonal with a long dry season \\
6 & $1.00-1.19$ & Most rainfall in 3 months or less \\
7 & $\geq 1.20$ & Extreme, almost all rain falls within 1-2 months \\
\hline & & Source: Walsh and Lawler, 1981
\end{tabular}

Specific Water Consumption (SWC) is the water equivalence to avert drought in an area where rainfall is deficient. It is the exact amount of water that will be required to irrigate a field for effective plant growth, development and yield. This is the quantity of water needed to bring field planted with crops to a point where the hydrologic ratio will be equal to unity. This was mathematically determined using the following equation (Stern and Dale 1982):

$S W C=D_{\text {wet }}\left(Q_{\text {wet }}-P_{\text {wet }}\right)+D_{\text {dry }}\left(Q_{\text {dry }}-P_{\text {dry }}\right)$, where: 
SWC = Specific Water Consumption

$D_{\text {wet }}=$ Length of wet period in days

$Q_{\text {wet }}=$ Water demand equivalence of $P E$ during wet period ( $\mathrm{mm} /$ day)

$\mathrm{P}_{\text {wet }}=$ Average daily precipitation during wet period

$D_{\text {dry }}=$ Number of dry days during the rainy season

$Q_{\text {dry }}=$ Maximum water demand equivalence of $P E$ during dry period

$\mathrm{P}_{\text {dry }}=$ Average daily precipitation during dry period (mm/day)

$\mathrm{PE}=$ Potential Evapotranspiration

Fohn et al (1974, in Sawa and Adebayo 2015) suggested the use of adjusted $Q_{\text {wet }}$ values for specific latitudinal locations. For semi-arid environments (latitude $10^{\circ}-20^{\circ}$ ) where water demand is very high, the values computed and suggested for used are $Q_{\text {wet }}$ is $4.78 \mathrm{~mm}$ and $Q_{\text {dry }}$ is $3.88 \mathrm{~mm}$. These adjusted values were used in this research.

\subsection{RESULTS}

The results of this research are presented under two subheadings for simplicity and clarity. The characteristics of climatic variables are meant to show the central tendencies, measures of dispersion and trend in both rainfall and temperature for the 43 years' period of the study. On the other hand, precipitation effectiveness indices is to reveal how sufficient or otherwise of rainfall to support crop production and ensure ecological balance.

\subsection{Characteristics of Climatic Variables}

The statistics of rainfall and temperature data analyzed reveal high level of variability in their trend. The highest annual total rainfall of $712.10 \mathrm{~mm}$ was recorded in 2015 and a minimum of $224.70 \mathrm{~mm}$ in 1983 . The highest value in 2015 coincided with the year that Nigeria generally experienced high amount of rainfall with consequent flood incidences that left its toll in the economy of the nation. A mean annual total of $432.3 \mathrm{~mm}$ was derived for the study period; an evidence of a typical semi-arid region. A standard deviation of 9.48 and variance of 89.9 (Table 2) are further indications that rainfall is highly variable, which portends a danger to rainfed agriculture. Generally, rainfall reaches its peak in August in the area, even though there seems to be a shift in the trend to July. In the same vein, temperature is high throughout the the year with mean annual total values ranging from $33.20^{\circ} \mathrm{C}$ in 1980 to $36.92^{\circ} \mathrm{C}$ in 1997. The average maximum temperature was calculated to be $44.20^{\circ} \mathrm{C}$ (in 1983), meaning that diurnal maximum temperature can be as high as between $45-47^{\circ} \mathrm{C}$, especially during the hotter months of April and May. Standard deviation and variance of 2.84 and 8.11 respectively are indications that, unlike rainfall, temperature is uniformly high in the area.

Table 2: Descriptive Statistics of Total Annual Rainfall and Temperature of the Study Area

\begin{tabular}{|c|c|c|c|c|c|c|c|c|}
\hline & \multirow{2}{*}{\begin{tabular}{l|}
$\mathrm{N}$ \\
Statist \\
ic
\end{tabular}} & \multirow{2}{*}{\begin{tabular}{|l|} 
Range \\
Statisti \\
c \\
\end{tabular}} & \multirow{2}{*}{$\begin{array}{l}\text { Minimu } \\
\mathrm{m} \\
\text { Statistic }\end{array}$} & \multirow{2}{*}{$\begin{array}{l}\text { Maximu } \\
\mathrm{m} \\
\text { Statistic }\end{array}$} & \multicolumn{2}{|l|}{ Mean } & \multirow{2}{*}{\begin{tabular}{|l|}
$\begin{array}{l}\text { Std. } \\
\text { Deviation }\end{array}$ \\
Statistic \\
\end{tabular}} & \multirow{2}{*}{\begin{tabular}{|l} 
Variance \\
Statistic
\end{tabular}} \\
\hline & & & & & $\begin{array}{l}\text { Statisti } \\
\mathrm{C}\end{array}$ & \begin{tabular}{|l} 
Std. \\
Error
\end{tabular} & & \\
\hline $\begin{array}{l}\text { Rainfall } \\
\text { Temperature } \\
\text { Valid } \quad \mathrm{N} \\
\text { (listwise) }\end{array}$ & $\begin{array}{l}43 \\
43 \\
43\end{array}$ & \begin{tabular}{|l|}
487.40 \\
8.98
\end{tabular} & $\begin{array}{l}224.70 \\
23.40\end{array}$ & $\begin{array}{l}712.10 \\
44.20\end{array}$ & $\begin{array}{l}36.04 \\
34.44\end{array}$ & $\begin{array}{l}1.48 \\
0.82\end{array}$ & $\begin{array}{l}9.48 \\
2.84\end{array}$ & \begin{tabular}{|l}
89.90 \\
8.11
\end{tabular} \\
\hline
\end{tabular}

In order to visualize the pattern and degree of change in the occurrence of temperature, rainfall and by extension precipitation effectiveness indices, their values were subjected to time series analysis, where 5-year moving average and linear trend line equations were determined. Fig 2 indicates clearly that there is an increasing trend in the temperature. The equation exhibits a positive trend with a negative intercept $(\mathrm{y}=$ $0.0242 x-13.006)$ meaning an increasing hot period in the area. Rainfall trend exhibits a similar pattern (Fig 3). There is an increase in rainfall but with decreasing length of period taken to fall $(y=0.1143 x-191.78)$ in the study

area. 


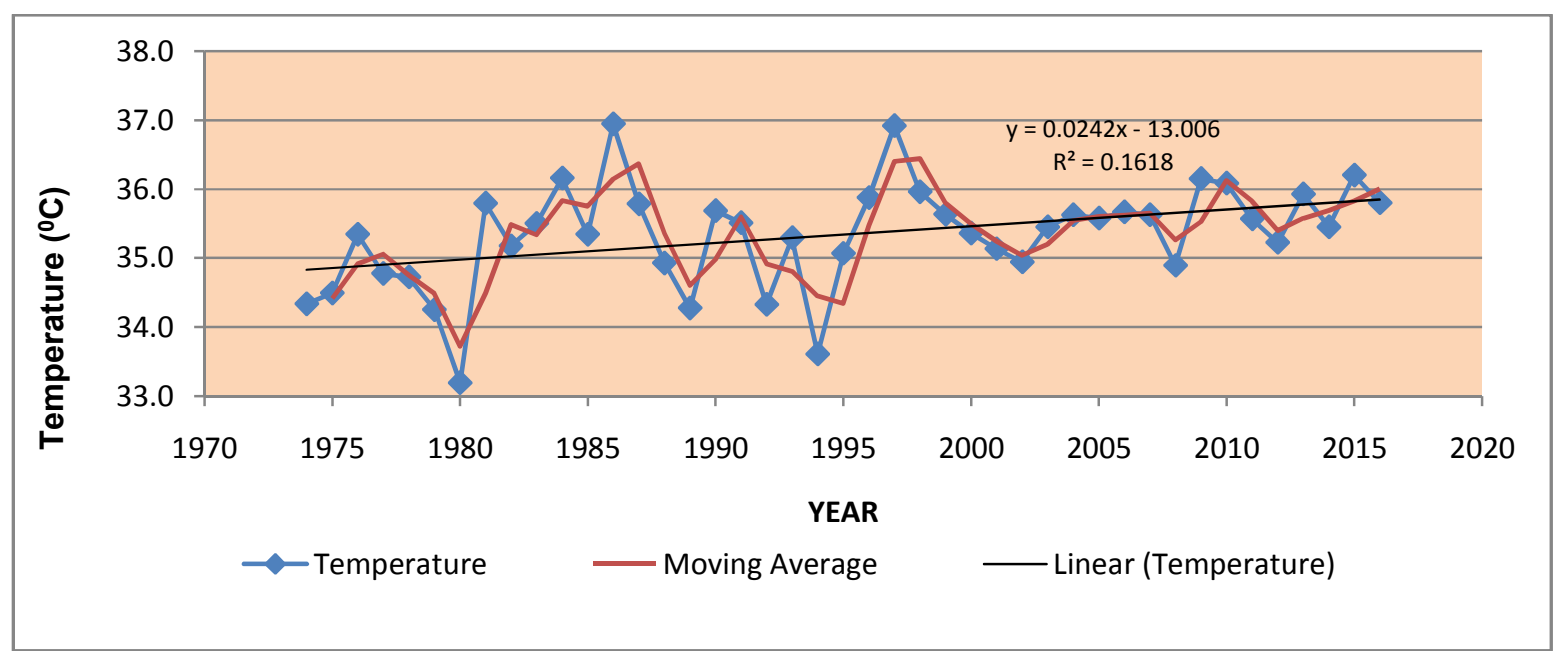

Fig. 2: Mean Annual Temperature of the study Area 1974-2016

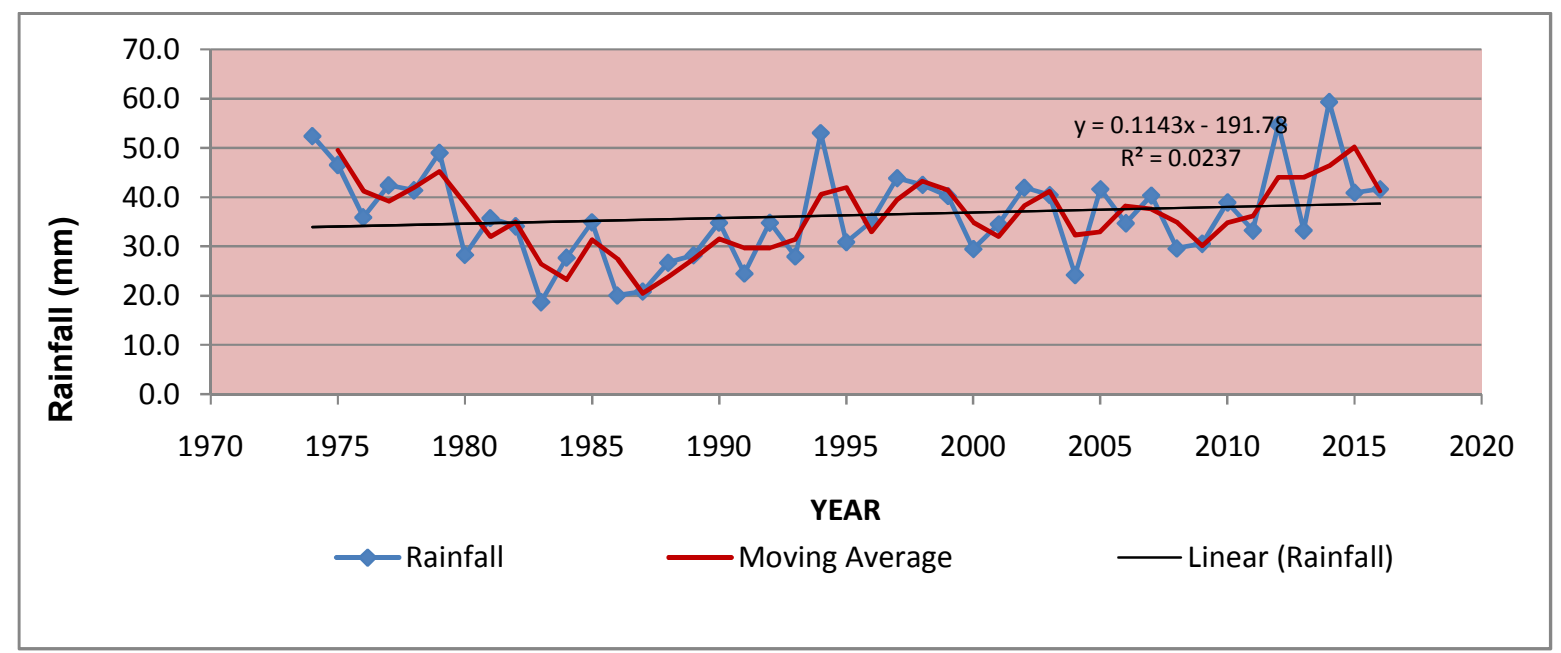

Fig. 3: Mean Annual Rainfall of the study Area 1974-2016

\subsection{Precipitation Effectiveness Indices}

The precipitation effectiveness indices or variables were derived from climatic parameter of rainfall with a view to assessing its availability or deficiency as it affects agriculture in particular and appropriateness of ecosystem survival in general in the study area. Principally, results of precipitation effectiveness indices generated included the following:

\subsubsection{Onset and Cessation Dates of Rains}

The approximate onset date or start of rain in the study area was computed to be on $14^{\text {th }}$ June. This represents the date on which farmers are expected to commence planting of crops. However, because of variations in the latitudinal locations of the area $\left(11^{\circ} 30^{\prime}\right.$ $-13^{0} 30^{\prime}$ ), the variations in the planting dates was found to be between June $1^{\text {st }}$ (in the southernmost part e.g. Jakusku) to $23^{\text {rd }}$ June (around Yusufari and Yunusari areas). End of rainy season begins around September $19^{\text {th }}$ in the far north and moves gradually towards the south until it reaches the southernmost axis around October $2^{\text {nd }}$. Approximately, the mean cessation date of rains in the area is September $25^{\text {th }}$. Generally, gradual increase of delay in onset and early cessation dates were observed.

\subsubsection{Length of Rainy Season (LRS)}

The average length of rainy season in the study area was found to be 89 days, i.e. about 3 months. The length of rainy season decreases with increasing latitude in the area. The length of rainy season is of great importance to farmers as it guides them as to what types of crops can be grown where, based on the duration of days required by the plants to mature to harvesting stage. This is why crops grown could be classified into long, moderate and short duration crops. On the other hand, the length of rainy season also determines types and viability of natural plants found in an area. This is why the short rainfall duration areas are associated with aridity.

\subsubsection{Hydrologic Ratio}

This is the ratio of rainfall to potential evapotranspiration. The higher the potential evapotranspiration, the lower the ratio and vice-versa. Hydrologic ratio of the area was derived to be 0.255 , which falls within the arid zone values of between 0.3 to 0.6 (Stern and Dale 1982). What this means is that the area is comparatively drier compared to other zones in Nigeria. It also means that the area is more prone to dry spells, which is an evidence of desertification process. 


\subsubsection{Rainfall Seasonality Index and Specific Water Consumption}

Seasonality index refers to the spread and steadiness of the rainy season. A seasonality index of 1.18 was obtained for the study area. Comparing this value to the Walsh and Lawler's (1981) values in Table 2 means that the area is markedly seasonal with rain falling in just 3 months or less. This higher value indicating that the rain falls within shorter periods (3months), also implies that the area has low rainfall. This corroborates the average annual rainfall totals of just $432.3 \mathrm{~mm}$ derived from 43years data used in this research. It also agrees with the onset and cessation dates results and length of rainy season values (89days). This coupled with the lower hydrologic ratio value of 0.255 , points to the fact that the area lacks sufficient rainfall to neutralize potential conditions leading to desertification occurrence. It can however, be concluded that given late onset of rains (June $14^{\text {th }}$ ), early cessation of rains (September $25^{\text {th }}$ ), shorter length of rainy season (89days), and high seasonality index (1.18), there is high evidence of increased aridity in the area. It is also evident that rains are neither effective for high crop yield nor available to ensure palatable ecosystem in the area. This results to insufficient available surface water for irrigation and other purposes. It also means that only crops and plants that require little rainfall and are drought resistant that can thrive effectively in this area.

\section{CONCLUSION}

Based on the findings of this research, it can be concluded that climatic variables in northern Yobe is highly fluctuation. Rain falls in the area within 3 months with onset dates gradually occurring late and cessation dates gradually coming early. Hydrologic ratio was observed to be higher, an indicative of a typical arid zone in addition to high seasonality index. This coupled with high temperature throughout the year leads to high evapotranspiration. Trend line equations further suggest that rainfall and temperature are increasing in values with maximum values concentrated within short period.

\section{Implications of the Findings}

The findings of this research have implications for both agriculture in particular and ecosystem in general of the area. The high fluctuating nature of the climatic variables portends high prospect of dry spells. Dry spell is a climatic condition where rain ceases to come for a period of time. This poses great danger as it leads to loss of plants and animals as well as depletion of biodiversity. The unpredictable nature of the weather does not only constitutes problems of not allowing for proper planning of when exactly to plant but leads to early cessation of rain, thereby leading to crops failure and overstressing of natural plants. The late onset and early cessation of rains, high degree of dryness (hydrologic ratio), high value of seasonality index and low quantity of water needed all point to the fact that the area possesses characteristics of a typical arid zone. This means that only drought resistant plants can thrive successfully in the area, thereby giving farmers a limited alternative.

The region's insufficient surface water which poses great challenge to pastoralism is a najor constraint to economic activities. This results to obstruction in hydrological patterns, imbalance in plants species distribution and composition as well as plant productivity. Given this situation, farmers have to make extra efforts in order to provide water for crops and animals. This coupled with loss of biodiversity, due largely to land degradation, leading to disappearance of various animals and birds species resulting to their extinction and/or presenting them as highly endangered species.

Deliberate efforts should be geared towards close monitoring and prediction of climate to guide economic activities in the area. This should be done by establishing adequate weather stations for data collection and analysis. Massive tree planting campaign should also be mounted to sensitize the locals on what needs to be done and avoided so as to ensure sustainable development in the area.

\section{REFERENCES}

Adams, W. M. and Hollis, G. E., 1987. Hydrology and Sustainable Resources Development of Sahelian Floodplain, Report to Hadejia-Nguru Wetlands Conservation Project, Nguru Nigeria.

Adebayo, A. A. and Adebayo, E. F., 1997. Precipitation Effectiveness Indices and Upland Rice Yield in Adamwa State, Annals Borno, 13/14: 266-276.

Adefolalu, D. O., 1993. World Meteorological Organization, Lecture Series 1: 1-4.

Adefolalu, D. O., 1998. Precipitation, Evapotranspiration and the Ecological Zones in Nigeria, Theor. Appl. Climatol., 39: 81-89.

Adetunji, A. M., 2006. Desertification in the Nigerian Environment, National Open University of Nigeria Lagos.

Ellis, J. E., Coughenour, M. B. and Swift, D. M., 1993. Climatic Variability, Ecosystem Stability and the Implications for Range and Livestock Management. In Behnke R.H., Scoones I., and Kevin C. (eds) Range Ecology at Disequillibrium, Overseas Development Institute, London, p31-41.

Emodu, E. E., 2013. Drought and Desertification as they Affect Nigerian Environment, Journal of Environmental Management and Safety.

FAO., 2006. Global Forest Resource Management (FRA 2005) Food and Agriculture Organization of the United Nations, http//www.fao.org/forestry/32085/en, retrieved in 2016.

Graetz, R. D., 1996. Empirical and Practical Approaches to Land Surface Characterization and Change Detection. In: Hill J. and Peter D. (eds) Planning for Climate Change, CSIRO, Melbourne, p399420.

Haruna, D. M. and Bukar, S., 2010. Integrated Remote Sensing Approach to Desertification Monitoring 
in the Crop Rangeland Area of Yobe State, Nigeria, Journal of Sustainable Development in Africa, 17: 217-228.

Hellden, U., 1988. Desertification Monitoring: Is the Desert Encroaching? Desertification Control Bulletin, UNEP Nairobi 17, 8-12.

Hill, J. and Peter, D., 1996. Preface, In: Hill J. and Peter D. (eds) The Use of Remote Sensing for Land Degradation and Desertification Monitoring in the Mediterranean Basin. European Commission, Brussels, pv-vi.

Huenneke, L. F., Anderson, J. P., Remmenga, M. and Schlesinger, W., 2002. Desertification alters patterns of above ground net primary production in Chihuahuan ecosystems, Global Change Biology, 8, 247-264.

Kowal, J. M. and Knabe, D. T., 1972. An Agro-climatic Atlas of Northern States of Nigeria, Ahmadu Bello University Press, Zaria, 111.

Lamprey, H. F., 1975. Report on the Desert Encroachment Reconnaissance in Northern Sudan, $21^{\text {st }}$ Oct $-10^{\text {th }}$ Nov 1975, UNESCO/UNEP, Paris/Nairobi, Republished in Desertification Bulletin 17, 1-7.

Le Houerou, H. N., 2002. Mand-made Deserts: Desertification Processes and Threats, Arid Land Research Management, 16, 1-36.

Mainguet, M., 1994. What is Desertification? Definitions and Evolution of the Concept, Desertification Natural Background and Human Mismanagement, Springer, Berlin. 1-16.

Nicholson, S. E., Tucker, C. J. and Ba, M. B., 1998. Desertification, Drought and Surface Vegetation: An Example from the West African Sahel, Bulletin of the American Meteorological Society $79,815-829$.

Olagunju, and Temidayo, E., 2015. Drought, Desertification and the Nigerian Environment: A Review, Journal of Ecology and the Natural Environment, vol. 7, 7 .

Olaniran, O. J., 1988. The Distribution in Space of Raindays of Rainfall of Different Amounts in the Tropics: Nigeria as a Case Study, Geoforum, 19(4): 507-520.

Pickup, G., 1996. Estimating the Effects of Land Degradation and Rainfall Variation on Productivity of Rangelands: An Approach Using Remote Sensing and Models of Grazing and Herbage Dynamics, Journal of Applied Ecology $33,819-832$.

Prince, S. D., Brown de Colstoun, E. and Kravitz, L. L., 1998. Evidence from Rain-use Efficiencies does not Indicate Extensive Sahelian Desertification, Global Change Biology, 4, 359-374.
Reynolds, J. F. and Stafford Smith, D. M., 2002. Global Desertification: Do Humans Cause Deserts? 88, Dahlem University Press, Berlin.

Sawa, B. A. and Adebayo, A. A., 2015. Derived Rainfall Effectiveness Indices as Evidence of Climate Change in Northern Nigeria and Implications for Food Security, Journal of Agriculture and Biodiversity Research, 4(2) 26-36.

Stern, R. D. and Dale, I. C., 1982. Statistical Methods for Tropical Drought Analysis based on Rainfall Data. Project AZI: A Report on Data Requirements for Estimating the Likelihood of Droughts. WMO Programme Res.Trop. Meteorol., (PRTM), 35.

Tucker, C. J., Dregne, H. E. and Newcomb, W. W., 1991. Expansion and Contraction of the Sahara Desert from 1980 to 1990, Science 253, 299-301.

Umar, Y., 2015. Assessment of Desertification and its Impact on Agricultural Lands in Northeastern Yobe State, Unpublished M.Sc. Thesis submitted to Geography Department, Modibbo Adama University of Technology, Yola.

UNEP., 1992. United Nations Environmental Program, World Atlas of Desertification (Editorial Commentary by N. Middleton and D.S.G. Thomas) Arnold, London.

United Nations., UN 1994. UN Earth Summit, Convention on Desertification, UN Conference in Environment and Development, Rio de Janeiro, Brazil, June 3-14 1992 DPI/SD/1576, United Nations, New York.

UNCCD., 2000. Assessment of the Status of Land Degradation in Arid, Semi-arid and Dry Subhumid Areas. United Nations Convention to Combat Desertification, Bonn.

Veron, S. R., Oesterheld, M. and Paruelo, J. M., 2005. Production as a Function of Resource Availability: Slopes and Efficiencies are Different, Journal of Vegetation Science, 16, 351-354.

Walsh, P. R. D. and Lawler, D. M., 1981. Rainfall Seasonality Description, Spatial Pattern and Change through Time. Weather, 36(7): 201-208.

Walter, M. W., 1967. Length of the Rainy Season in Nigeria, Nigerian Geographic Journal, 10: 123128.

Warren, A. and Khogali, M., 1992. An Assessment of Desertification and Drought in the SudanoSahelian Region, United Nations SudanoSahelian Office, New York.

Williams, M. A. J. and Bailing, R. C., 1996 Interactions of Desertification and Climate, Arnold, London. 
